\title{
Statistical Evaluation of Production Scenario of Kharif Pulses in Odisha, India
}

\author{
Abhiram Dash* and Soumya Prusty \\ Odisha University of Agriculture and Technology, Odisha, India \\ *Corresponding author
}

K e y w o r d s
Compound Growth
Rate, Cuddy-Della
Instability Index,
production,
significant

\section{A B S T R A C T}

The state of Odisha having an agrarian based economy depends largely on agriculture for the livelihood of its population. Pulses are important commodity group of crops that provides high quality protein complementing cereal proteins for predominantly substantial vegetatarian population of the country. Pulses are grown in all the 30 districts of Odisha. Major pulses grown in Odisha are black gram, green gram, arhar, cowpea chickpea etc. A study on the compound growth rate and variability of area, yield and production of pulses for kharif season in the districts of Odisha and the state as a whole. has been attempted. Then the districts of Odisha are ranked on the basis of decreasing compound growth rate and increasing instability index of area, yield and production of kharif pulses. The performance of area and yield of kharif pulses is found to be quite well which leads to good performance in production. To get a good increment in growth rate of area and yield of kharif pulses along with low degree of instability, more area should be brought under pulses during kharif season if possible and improved cultivation practices must be adopted.

\section{Introduction}

The state of Odisha having an agriculture based economy depends largely on agriculture for the mainstay of the population. Types of crops grown in Odisha include cereals, pulses, millets, plantation crops like coffee etc. Major pulses grown in Odisha are black gram, green gram, arhar, cowpea chickpea etc. Pulses are grown in all the 30 districts of Odisha. At present pulses are grown in around 2080 thousand ha area with production of 1060 thousand tonnes and productivity of $508 \mathrm{~kg} /$ ha. The Mahanadi delta, Rushikulya plains, Hirakud and Badimula regions are favourable for cultivation of pulses. Rusikulya plain is the most important agricultural region of Odisha and dominated by pulse crops. Odisha covers nearly about 9\% area and 8\% production of pulses as compared to the total area and production of pulses in India respectively. Kharif pulses constitute 33\% area and $36 \%$ production with productivity of $559 \mathrm{~kg} / \mathrm{ha}$. 
Twenty districts have productivity of 400-500 $\mathrm{kg} / \mathrm{ha}, 9$ districts having average yield of $>500 \mathrm{~kg} / \mathrm{ha}$ and one district i.e. Deogarh has productivity of $<400 \mathrm{~kg} / \mathrm{ha}$. Dash, et al., (2017) studied the growth rate and instability of area, yield and production of food grains in Odisha using the best fit model and the model selected on the basis of scatter plot of the data.

This study helps to the policy makers to get an idea about the future requirements, enabling to take appropriate measures like selection of high yielding varieties, conducting training to farmers to improve cultural practices, adequate supply of inputs and use of latest technologies. Import and export of these pulse crops can also be planned.

The compound growth rate and variability of area, yield and production of pulses for kharif season in the districts of Odisha and the state as a whole are studied first. Then the districts of Odisha are ranked on the basis of decreasing compound growth rate and increasing instability index of area, yield and production of kharif pulses. The Spearman's rank correlation between compound growth rate and instability index of area, yield and production of kharif pulses is also being computed.

Keeping in view the above perspectives the study has been made regarding area, yield and production of pulses in all the 30 districts of Odisha for kharif seasons for the period from 1993-94 to 2016-17.

\section{Materials and Methods}

The study is based on secondary source of data on area, production and yield of pulse crops for kharif season in the districts of Odisha from the period 1993-94 to 2016-17. The data are obtained from various volumes of Odisha Agriculture Statistic published by Directorate of Agriculture and Food Production, Government of Odisha.

\section{Compound growth rate (CGR)}

The data on area, production and yield of pulse crops for kharif season in Odisha were worked out for entire period of analysis by fitting to exponential functions as follows.

$Y_{t}=a b^{t}$

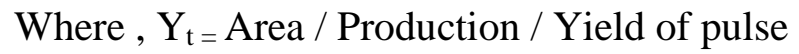
crops in years.

$\mathrm{t}=$ time element which takes the value $1,2,3, \ldots \ldots, \mathrm{n}$

$a=$ intercept $; b=$ regression coefficient

The compound growth model is established in the following manner,

$\ln \mathrm{Y}_{\mathrm{t}}=\ln \mathrm{a}+\mathrm{t} \ln \mathrm{b}$

$\mathrm{Y}_{\mathrm{t}}^{\prime}=\mathrm{A}^{\prime}+\mathrm{B}^{\prime} \mathrm{t}$

Let $\ln \mathrm{Y}_{\mathrm{t}}=\mathrm{Y}_{\mathrm{t}}{ }^{\prime}$

$\ln \mathrm{a}=\mathrm{A}^{\prime}$

$\ln b=B^{\prime}$

The two generalised equations are

$$
\begin{aligned}
& \sum_{t=1}^{n} Y_{t}^{t}=\sum_{t=1}^{n}\left(A^{l}+B^{l} t\right) \\
& \sum_{\mathrm{t}=1}^{\mathrm{n}} \mathrm{Y}_{\mathrm{t}}^{\mathrm{l}}=\mathrm{n} \mathrm{A}^{\mathrm{l}}+\mathrm{B}^{\mathrm{i}} \sum_{\mathrm{t}=1}^{\mathrm{n}} \mathrm{t} \\
& \sum_{\mathrm{t}=1}^{\mathrm{n}} \mathrm{tY}_{\mathrm{t}}^{\mathrm{l}}=\mathrm{A}^{\mathrm{i}} \sum_{\mathrm{t}=1}^{\mathrm{n}} \mathrm{t}+\mathrm{B}^{\mathrm{i}} \sum_{\mathrm{t}=1}^{\mathrm{n}} \mathrm{t}^{2}
\end{aligned}
$$
...equation 1 ... equation 2

Solving the two equations and multiplying equation 1 by $\sum_{\mathrm{t}=1}^{\mathrm{n}} \mathrm{t}$ on both sides we get 


$$
\sum_{\mathrm{t}=1}^{\mathrm{n}} \mathrm{Y}_{\mathrm{t}}^{\mathrm{i}} \cdot \sum_{\mathrm{t}=1}^{\mathrm{n}} \mathrm{t}=\mathrm{nA} \mathrm{A}^{\mathrm{i}} \sum_{\mathrm{t}=1}^{\mathrm{n}} \mathrm{t}+\mathrm{B}^{\mathrm{i}}\left(\sum_{\mathrm{t}=}^{\mathrm{n}} \mathrm{t}\right)^{2}
$$

Multiplying equation 2 by $n$ on both sides we get

$\mathrm{n} \sum_{\mathrm{t}=1}^{\mathrm{n}} \mathrm{t} Y_{\mathrm{t}}^{\mathrm{i}}=\mathrm{nA} \mathrm{A}^{\mathrm{i}} \sum_{\mathrm{t}=1}^{\mathrm{n}} \mathrm{t}+\mathrm{nB} \mathrm{B}^{\mathrm{i}} \sum_{\mathrm{t}=1}^{\mathrm{n}} \mathrm{t}^{2}$ ...equation 4

By Equation 3 - Equation 4 we get

$\mathrm{n} \sum_{\mathrm{t}=1}^{\mathrm{n}} \mathrm{tY}_{\mathrm{t}}^{\mathrm{l}}-\sum_{\mathrm{t}=1}^{\mathrm{n}} \mathrm{Y}_{\mathrm{t}}^{\mathrm{i}} \cdot \sum_{\mathrm{t}=1}^{\mathrm{n}} \mathrm{t}=\mathrm{nB}^{1} \sum_{\mathrm{t}=1}^{\mathrm{n}} \mathrm{t}^{2}-\mathrm{B}^{\mathrm{l}}\left(\sum_{\mathrm{t}=1}^{\mathrm{n}} \mathrm{t}\right)^{2}$

$\Rightarrow B^{\prime}=\frac{\mathrm{n} \sum_{\mathrm{t}=1}^{\mathrm{n}} \mathrm{t} \mathrm{Y}_{\mathrm{t}}^{\mathrm{t}}-\sum_{\mathrm{t}=1}^{\mathrm{n}} \mathrm{t} \cdot \sum_{\mathrm{t}=1}^{\mathrm{n}} \mathrm{Y}_{\mathrm{t}}^{\mathrm{t}}}{\mathrm{n} \sum_{\mathrm{t}=1}^{\mathrm{n}} \mathrm{t}^{2}-\left(\sum_{\mathrm{t}=1}^{\mathrm{n}} \mathrm{t}\right)^{2}}$

Putting the value of $\mathrm{B}^{\prime}$ in equation 1 we get

$A=\left(\sum_{t=}^{n} Y_{t}^{i}-B \sum_{t=1}^{n} t\right) / n$

$A=\left(\sum_{t=}^{n} Y_{t}^{i}-B \sum_{t=1}^{n} t\right) / n$

Given,

$\ln \mathrm{a}=\mathrm{A}^{\prime} ; \mathrm{a}=\mathrm{e}^{\mathrm{A}^{\prime}} ; \ln \mathrm{b}=\mathrm{B}^{\prime} ; \mathrm{b}=\mathrm{e}^{\mathrm{B}^{\prime}}$

Compound growth rate $($ C.G.R.) $=(b-1) X$ 100

$\mathrm{SE}(\mathrm{CGR})=\ln (\mathrm{b}) \quad \mathrm{x} \quad \mathrm{SE}(\ln \quad \mathrm{b}) / \ln 10$ (Dhakre and Sharma, 2010)

\section{Cuddy- Della instability index}

Cuddy- Della Instability Index is most commonly used measures of instability of time series data and is universally acceptable. The indices were originally developed by John Cuddy and Della Valle for measuring the instability in time series data. This index is a better measure compared to coefficient of variation, as it is inherently adjusted for trend, often observed in time series data. This measure included as a component of instability all cyclical fluctuations present in the time series data, whether regular or irregular, as well as any component which could be defined as 'white noise'.

Cuddy-Della Instability Index (CDII) is given as,

$\mathrm{CDII}=\mathrm{CV} \times \sqrt{1-\mathrm{R}^{2}} \quad($ Kumar et al., 2018)

Where,

$\mathrm{CV}=$ Coefficient of variation $=\frac{\sigma}{\bar{Y}} \times 100$

$\sigma-$ Standard Deviation of Mean

Area/Yield/Production;

$\bar{Y}$ - Mean Area/Yield/Production

$\mathrm{R}^{2}$ - Coefficient of determination from a time trend regression adjusted for its degree of freedom

\section{Spearman's rank correlation coefficient}

Spearman's rank correlation coefficient denoted by $\rho$ is a nonparametric measure of rank correlation. It assesses how well the relationship between two variables can be described using monotonic function.

The Spearman's correlation between two variables is equal to the Karl Pearson's correlation coefficient between rank values of those two variables and Pearson's correlation assesses linear relationships.

Spearman's formula for rank correlation coefficient,

$$
\rho=\frac{1-6 \sum_{i=1}^{n} d_{i}^{2}}{n\left(n^{2}-1\right)}
$$

Where, 
$d_{i}=$ difference between two ranks of each observations

$\mathrm{n}=$ number of observations

\section{Test of significance of correlation coefficient}

The significance of the correlation is tested using t- test.

Let us assume the population correlation coefficient $(\rho)$ between Area \& Production and Yield \& Production be zero. So,

$\mathrm{H}_{0}: \rho=0$

$\mathrm{H}_{1}: \rho \neq 0$

Level of significance $(\alpha)=0.05(5 \%)$ or $0.01(1 \%)$

Test statistic is given by

$\mathrm{t}_{\mathrm{Cal}}=\frac{\mathrm{r}}{\mathrm{SE}(\mathrm{r})}$

$\mathrm{SE}(\mathrm{r})=\frac{1-\mathrm{r}^{2}}{\mathrm{n}-2}$

Tabulated $\mathrm{t}$ values are obtained from $\mathrm{t}$-table. Tab t values are found for 0.05 and 0.01 level of significance at (n-2) d.f as the case may be.

Let the Tabulated $\mathrm{t}$ value for 0.05 and 0.01 level of significance be represented by $t_{1}$ and $\mathrm{t}_{2}$ respectively.

If $\left|t_{\text {cal }}\right|>\mathrm{t}_{2}$ then we reject the null hypothesis at $1 \%$ level of significance. Here $t$ is considered to be highly significant and correlation between Area- Production and Yield -Production of two periods differ significantly at $1 \%$ level of significance.

If $\left|t_{c a l}\right|<t_{1}$ we accept null hypothesis. Here $t$ is considered to be insignificant and we conclude that correlation don't differ significantly. If $\mathrm{t}_{1}<\left|t_{c a l}\right|<\mathrm{t}_{2}$, then we reject null hypothesis only at 5\% level of significance. Here $\mathrm{t}$ is considered to be significant and we conclude that correlation differs significantly at 5\% level of significance.

\section{Results and Discussion}

Table 1 shows that though the compound growth rate of both area and yield of kharif pulses in Odisha is positive and significant which leads to positive and significant compound growth rate of production of kharif pulses. Among the districts almost all districts show significantly positive compound growth rate of area under kharif pulses except a few like Balasore, Cuttack, Puri and Nabrangpur which show significantly negative compound growth rate of area under kharif pulses Most of the districts show positive compound growth rate in yield which is also significant. Only a few districts like Gajapati, Jagatsinghpur, Kendrapada, Nayagarh and Puri show negative and significant compound growth rate in yield of kharif food grains, whereas, the remaining districts show significantly positive compound growth rate of yield. The compound growth rate of production is also positive and significant in many districts except a few like Balasore, Cuttack and Puri.

Table 2 shows that in Odisha Instability is highest in case of production of kharif pulses than that in area and yield. Thus the higher instability in production is due to interaction effect of area and yield. The districts like Balasore and Puri have very high rate of ri in production of kharif pulses which goes above $45 \%$. Remaining districts have comparatively low instability in production. The instability in area and yield of kharif pulses is below $50 \%$ for all districts of Odisha though some districts like Balasore and Kendrapada which have quite high rate (above 45\%) of 
instability. Table 3 shows that Sonepur district secured the first rank with respect to compound growth rate of area under kharif pulses followed by Boudh. Balasore districts has the last rank among the districts of Odisha on compound growth rate of area under kharif pulses. In case of instability of area under kharif pulses, Bolangir occupied the first position followed by Kandhmal and the last position is occupied by Puri district.

In case of compound growth rate of yield of kharif pulses as evident from table 4, Balasore also secured first position followed by Nuapada and last rank is occupied by Puri. Boudh secured first position followed by Sonepur district and last rank is occupied by
Balasore with respect to I=instability in yield of kharif pulses. Table 5 shows that in case of compound growth rate of production of kharif pulses, Nuapada district occupied the first position followed by Sonepur and the last position is occupied by Balasore district. Kandhmal secured first position followed by Bolangir district and last rank is occupied by Puri with respect to instability in production of kharif pulses.

Table 6 which show the rank correlation coefficient between the compound growth rate and instability of area, yield and production of kharif pulses in Odisha, reveals that the rank correltion is non-significant in all cases.

Table.1 Compound Growth Rate of kharif pulses of different districts of Odisha (in per cent)

\begin{tabular}{|c|c|c|c|c|c|c|c|c|c|}
\hline $\begin{array}{l}\text { Sl. } \\
\text { No. }\end{array}$ & Districts & Area & Yield & Production & $\begin{array}{l}\text { SI. } \\
\text { No }\end{array}$ & Districts & Area & Yield & Production \\
\hline 1 & Anugul & $1.05^{* *}$ & $1.79 * *$ & $3.01 * *$ & 16 & Kandhamal & 0.05 & $0.29 * *$ & $0.34 * *$ \\
\hline 2 & Balasore & $-11.43 * *$ & $4.7 * *$ & $-7.2 * *$ & 17 & Kendrapada & -0.7 & $-0.89 * *$ & -1.5 \\
\hline 3 & Bargarh & $1.13^{* *}$ & $0.51 * *$ & $1.65 * *$ & 18 & Keonjhar & $1.55^{* *}$ & $1.22 * *$ & $2.79 * *$ \\
\hline 4 & Bhadrak & $2.23 * *$ & 0.11 & 0.49 & 19 & Khurda & -0.07 & $0.48 * *$ & 0.38 \\
\hline 5 & Bolangir & $0.71 * *$ & $2.9 * *$ & $3.64 * *$ & 20 & Koraput & $2.05^{* *}$ & $1.81^{* *}$ & $3.86^{* *}$ \\
\hline 6 & Boudh & $2.47 * *$ & $0.49 * *$ & $2.98 * *$ & 21 & Malkangiri & 0.79 & $0.39 * *$ & 1.18 \\
\hline 7 & Cuttack & $-0.95^{* *}$ & $-1.03^{* *}$ & $-1.9 * *$ & 22 & Mayurbhanj & $2.31 * *$ & 0.83 & $3.32 * *$ \\
\hline 8 & Deogarh & $2.18 * *$ & $0.77 * *$ & $2.97 * *$ & 23 & Nabarangpur & $-0.65^{* *}$ & $0.68 * *$ & 0.03 \\
\hline 9 & Dhenkanal & $-0.74 * *$ & $2.04 * *$ & $2.78 * *$ & 24 & Nayagarh & $1.2^{* *}$ & $-1.07 * *$ & 0.17 \\
\hline 10 & Gajapati & $2.37 * *$ & $-1.18 * *$ & $1.16^{* *}$ & 25 & Nuapada & $1.27 * *$ & $4.17 * *$ & $5.49 * *$ \\
\hline 11 & Ganjam & $0.86^{* *}$ & $0.74 * *$ & $1.61 * *$ & 26 & Puri & $-10.01 * *$ & $-3.35 * *$ & $-5.52 * *$ \\
\hline 12 & Jagatsinghpur & -1.18 & $-0.51 * *$ & -1.69 & 27 & Rayagada & $1.85^{* *}$ & $0.5^{* *}$ & $2.34 * *$ \\
\hline 13 & Jajpur & 0.19 & $0.4 * *$ & 0.59 & 28 & Sambalpur & $1.57 * *$ & $1.58 * *$ & $3.18 * *$ \\
\hline 14 & Jharsuguda & $1.52 * *$ & $0.89 * *$ & $2.42 * *$ & 29 & Sonepur & $3.26 * *$ & $4.08 * *$ & $3.25^{*}$ \\
\hline \multirow[t]{2}{*}{15} & Kalahandi & $1.74 * *$ & $1.32 * *$ & $3.09 * *$ & 30 & Sundargarh & $0.67 * *$ & $1.33 * *$ & $2.01 * *$ \\
\hline & Odisha & $1.00 * *$ & $0.40 * *$ & $1.40 * *$ & & & & & \\
\hline
\end{tabular}


Table.2 Cuddy-Della instability index of kharif pulses of different districts of Odisha (in percent)

\begin{tabular}{|l|l|l|l|l|l|l|l|l|l|}
\hline $\begin{array}{l}\text { SI } \\
\text { No. }\end{array}$ & Districts & Area & Yield & Production & $\begin{array}{l}\text { SI } \\
\text { No. }\end{array}$ & Districts & Area & Yield & Production \\
\hline $\mathbf{1}$ & Anugul & 10.63 & 28.04 & 28.69 & 16 & Kandhamal & 8.01 & 8.2 & 11.07 \\
\hline $\mathbf{2}$ & Balasore & 47.54 & 69.78 & 47.44 & 17 & Kendrapada & 60.97 & $22 . .18$ & 23.6 \\
\hline $\mathbf{3}$ & Bargarh & 9.66 & 20.92 & 16.31 & 18 & Keonjhar & 15.27 & 18.91 & 26.07 \\
\hline $\mathbf{4}$ & Bhadrak & 27.87 & 21.4 & 14.89 & 19 & Khurda & 10.99 & 19.03 & 20.7 \\
\hline $\mathbf{5}$ & Bolangir & 4.69 & 13.17 & 13.99 & 20 & Koraput & 15.1 & 19.91 & 30.42 \\
\hline $\mathbf{6}$ & Boudh & 24.4 & 6.62 & 21.6 & 21 & Malkangiri & 25.05 & 15.69 & 30.96 \\
\hline $\mathbf{7}$ & Cuttack & 25.18 & 20.19 & 29.97 & 22 & Mayurbhanj & 23.14 & 24.12 & 35.45 \\
\hline $\mathbf{8}$ & Deogarh & 30.15 & 20.7 & 19.87 & 23 & Nabarangpur & 27.1 & 17.14 & 30.47 \\
\hline $\mathbf{9}$ & Dhenkanal & 16.68 & 23.16 & 28.29 & 24 & Nayagarh & 17.44 & 31.95 & 25.98 \\
\hline $\mathbf{1 0}$ & Gajapati & 20.5 & 14.85 & 15.59 & 25 & Nuapada & 12.72 & 35.72 & 42.24 \\
\hline $\mathbf{1 1}$ & Ganjam & 12.1 & 8.8 & 20.58 & 26 & Puri & 100.8 & 35.91 & 49.93 \\
\hline $\mathbf{1 2}$ & Jagatsinghpur & 30.92 & 19.66 & 37.97 & 27 & Rayagada & 18.08 & 14.46 & 24.92 \\
\hline $\mathbf{1 3}$ & Jajpur & 19.58 & 18.76 & 27.57 & 28 & Sambalpur & 16.67 & 23.98 & 35.55 \\
\hline $\mathbf{1 4}$ & Jharsuguda & 22.52 & 17.75 & 30.43 & 29 & Sonepur & 14.86 & 8.14 & 17.17 \\
\hline $\mathbf{1 5}$ & Kalahandi & 19.09 & 10.97 & 18.98 & 30 & Sundargarh & 8.72 & 17.38 & 21.94 \\
\hline & Odisha & $\mathbf{1 2 . 9 3}$ & $\mathbf{1 4 . 2 1}$ & $\mathbf{2 4 . 8 9}$ & & & & & \\
\hline
\end{tabular}

Table.3 Rank of the districts on basis of Compound Growth Rate (C.G.R) and Cuddy-Della Instability Index (CDII) of area under pulses for kharif season

\begin{tabular}{|c|c|c|c|c|c|c|c|}
\hline \multirow[t]{2}{*}{ SI No. } & \multirow[t]{2}{*}{ Districts } & \multicolumn{2}{|c|}{ Kharif } & \multirow[t]{2}{*}{ SI No. } & \multirow[t]{2}{*}{ Districts } & \multicolumn{2}{|c|}{ Kharif } \\
\hline & & CGR & CDII & & & CGR & CDII \\
\hline 1 & Anugul & 16 & 5 & 16 & Kandhamal & 22 & 2 \\
\hline 2 & Balasore & 30 & 28 & 17 & Kendrapada & 25 & 29 \\
\hline 3 & Bargarh & 15 & 4 & 18 & Keonjhar & 11 & 11 \\
\hline 4 & Bhadrak & 5 & 25 & 19 & Khurda & 23 & 6 \\
\hline 5 & Bolangir & 19 & 1 & 20 & Koraput & 7 & 10 \\
\hline 6 & Boudh & 2 & 21 & 21 & Malkangir & 18 & 22 \\
\hline 7 & Cuttack & 27 & 23 & 22 & Mayurbhanj & 4 & 20 \\
\hline 8 & Deogarh & 6 & 26 & 23 & Nabarangpur & 24 & 24 \\
\hline 9 & Dhenkanal & 26 & 13 & 24 & Nayagarh & 14 & 14 \\
\hline 10 & Gajapati & 3 & 18 & 25 & Nuapada & 13 & 8 \\
\hline 11 & Ganjam & 17 & 7 & 26 & Puri & 29 & 30 \\
\hline 12 & Jagatsinghpur & 28 & 27 & 27 & Rayagada & 8 & 15 \\
\hline 13 & Jajpur & 21 & 17 & 28 & Sambalpur & 10 & 12 \\
\hline 14 & Jharsuguda & 12 & 19 & 29 & Sonepur & 1 & 9 \\
\hline 15 & Kalahandi & 9 & 16 & 30 & Sundargarh & 20 & 3 \\
\hline
\end{tabular}


Table.4 Rank of the districts on basis of Compound Growth Rate (C.G.R) and Cuddy-Della Instability Index(CDII) of yield under pulses for kharif season

\begin{tabular}{|l|l|c|c|l|l|c|c|}
\hline \multirow{2}{*}{ SI No. } & \multirow{2}{*}{ Districts } & \multicolumn{2}{|c|}{ Kharif } & SI No. & Districts & \multicolumn{2}{c|}{ Kharif } \\
\cline { 3 - 7 } & & CGR & CDII & & & CGR & CDII \\
\hline $\mathbf{1}$ & Anugul & 7 & 26 & 16 & Kandhamal & 23 & 3 \\
\hline $\mathbf{2}$ & Balasore & 1 & 30 & 17 & Kendrapada & 26 & 22 \\
\hline $\mathbf{3}$ & Bargarh & 17 & 20 & 18 & Keonjhar & 11 & 14 \\
\hline $\mathbf{4}$ & Bhadrak & 24 & 21 & 19 & Khurda & 20 & 15 \\
\hline $\mathbf{5}$ & Bolangir & 4 & 6 & 20 & Koraput & 6 & 17 \\
\hline $\mathbf{6}$ & Boudh & 19 & 1 & 21 & Malkangir & 22 & 9 \\
\hline $\mathbf{7}$ & Cuttack & 27 & 18 & 22 & Mayurbhanj & 13 & 25 \\
\hline $\mathbf{8}$ & Deogarh & 14 & 19 & 23 & Nabarangpur & 16 & 10 \\
\hline $\mathbf{9}$ & Dhenkanal & 5 & 23 & 24 & Nayagarh & 28 & 27 \\
\hline $\mathbf{1 0}$ & Gajapati & 29 & 8 & 25 & Nuapada & 2 & 28 \\
\hline $\mathbf{1 1}$ & Ganjam & 15 & 4 & 26 & Puri & 30 & 29 \\
\hline $\mathbf{1 2}$ & Jagatsinghpur & 25 & 16 & 27 & Rayagada & 18 & 7 \\
\hline $\mathbf{1 3}$ & Jajpur & 21 & 13 & 28 & Sambalpur & 8 & 24 \\
\hline $\mathbf{1 4}$ & Jharsuguda & 12 & 12 & 29 & Sonepur & 3 & 2 \\
\hline $\mathbf{1 5}$ & Kalahandi & 10 & 5 & 30 & Sundargarh & 9 & 11 \\
\hline
\end{tabular}

Table.5 Rank of the districts on basis of Compound Growth Rate ( C.G.R) and Cuddy-Della Instability Index(CDII) of production under pulses for kharif season

\begin{tabular}{|c|c|c|c|c|c|c|c|}
\hline \multirow{2}{*}{$\begin{array}{l}\text { SI } \\
\text { No. }\end{array}$} & \multirow[b]{2}{*}{ Districts } & \multicolumn{2}{|c|}{ Kharif } & \multirow[t]{2}{*}{ SI No. } & \multirow[t]{2}{*}{ Districts } & \multicolumn{2}{|c|}{ Kharif } \\
\hline & & CGR & CDII & & & CGR & CDII \\
\hline 1 & Anugul & 5 & 19 & 16 & Kandhamal & 24 & 1 \\
\hline 2 & Balasore & 30 & 29 & 17 & Kendrapada & 25 & 13 \\
\hline 3 & Bargarh & 11 & 5 & 18 & Keonjhar & 14 & 16 \\
\hline 4 & Bhadrak & 21 & 3 & 19 & Khurda & 22 & 10 \\
\hline 5 & Bolangir & 3 & 2 & 20 & Koraput & 10 & 21 \\
\hline 6 & Boudh & 6 & 11 & 21 & Malkangir & 23 & 24 \\
\hline 7 & Cuttack & 28 & 20 & 22 & Mayurbhanj & 16 & 25 \\
\hline 8 & Deogarh & 7 & 8 & 23 & Nabarangpur & 17 & 23 \\
\hline 9 & Dhenkanal & 8 & 18 & 24 & Nayagarh & 26 & 15 \\
\hline 10 & Gajapati & 15 & 4 & 25 & Nuapada & 1 & 28 \\
\hline 11 & Ganjam & 12 & 9 & 26 & Puri & 29 & 30 \\
\hline 12 & Jagatsinghpur & 27 & 27 & 27 & Rayagada & 20 & 14 \\
\hline 13 & Jajpur & 19 & 17 & 28 & Sambalpur & 13 & 26 \\
\hline 14 & Jharsuguda & 9 & 22 & 29 & Sonepur & 2 & 6 \\
\hline 15 & Kalahandi & 4 & 7 & 30 & Sundargarh & 18 & 12 \\
\hline
\end{tabular}


Table.6 Rank correlation coefficient (RCC) between Compound Growth Rate (CGR) and Cuddy Della instability index (CDII) for area, yield and production of kharif Pulses of Odisha

\begin{tabular}{|l|c|c|c|}
\hline & Area & Yield & Production \\
\hline RCC & 0.16 & -0.043 & 0.281 \\
\hline SE(standard erreor) & 0.186 & 0.189 & 0.181 \\
\hline t & 0.857 & -0.228 & 1.554 \\
\hline $\begin{array}{l}\text { Highly significant/Significant/Non } \\
\text { significant }\end{array}$ & Non-significant & Non-significant & Non-significant \\
\hline
\end{tabular}

The performance of area and yield of kharif pulses as revealed from the analytical study is found to be quite well which leads to good performance in production. Very few districts like Balasore, Cuttack and Puri show poor performance with respect to growth rate and instability in area, yield and production of kharif pulses. The performance should be enhanced to get a good increment in growth rate of are and yield of kharif pulses alongwith low degree of instability. This could probably be achieved by putting some more area under pulses during kharif season if possible and by adopting improved cultivation practices for increasing the growth rate and decreasing the instability of area and yield. These steps are necessary for increasing growth rate of kharif pulse production with decreased instability.

\section{References}

Dash, A. Dhakre, D.S and Bhattacharya, D. (2017). Study of Growth and Instability in Food Grain Production of Odisha. A statistical approach, Environment and Ecology, 35(4):354-355.

Dhakre, D.S. and Sharma, A. (2010). Growth Analysis of Area, Production and Productivity of Maize in Nagaland, Agriculture Science Digest, 30(2):140144

Kumar N.S., Joseph B, Muhammed J.(2018). Growth and Instability in Area, Production, andProductivity of Cassava (Manihot esculenta) in Kerala, International Journal of Advance Research, Ideas and Innovations in Technology.4(1):446-448

\section{How to cite this article:}

Abhiram Dash and Soumya Prusty. 2020. Statistical Evaluation of Production Scenario of Kharif Pulse in Odisha, India. Int.J.Curr.Microbiol.App.Sci. 9(05): 845-852. doi: https://doi.org/10.20546/ijcmas.2020.905.094 